\title{
A 25-Year Perspective of Status Asthmaticus
}

\author{
Herbert C. Mansmann, Jr.
}

\section{Introduction}

Acute severe asthma in children remains one of the leading causes of admission to the hospital, although last reported in $1972 .{ }^{1}$ This disease was the seventh most common diagnosis at 5 children's hospitals, fifth at 5 large general hospitals, and ninth at 10 median-sized general hospitals. While these data reflect the magnitude of the problem, there remains great diversity of the criteria for admission, as well as management before, during, and after hospitalization.

A prospective study of hospital admissions of asthmatic children has documented many of my preconceived notions about these patients. ${ }^{2}$ The mean number of admissions was 5.7, and $46 \%$ of school-aged patients had missed 4 weeks or more during the previous 12 months because of asthma. The frequency of readmission was four times higher in the socioeconomically disadvantaged as implied by a lower number of homes owned, larger families, and relative overcrowding. This study also suggested that the difference may be related to less drug usage as well as different admission criteria. The perceived ability or inability of the parent or patient to provide adequate care at home obviously must also play a role.

The mortality statistics for asthma have remained largely unchanged for over 30 years, ${ }^{3}$ in spite of major advances in treatment. Many patients now die "suddenly" outside the hospital. Yet, a surprising number still progress to death under medical supervision. This editorial suggests a need for the adoption of three principles to control asthma; education of patients, careful supervision, and prompt recognition and treatment of deterioration. All three are cornerstones of the successful management of status asthmaticus.

Whenever an acute, severe attack of asthma occurs, the parent and/or patient must be encouraged to seek help quickly. The results of delay have been well documented in an adult patient seen 4,55 , and $90 \mathrm{hr}$ after the onset of three attacks. ${ }^{4}$ The treatment was the same for each episode, but the rate of recovery was significantly different. Therapy started at $4 \mathrm{hr}$ resulted in $100 \%$ of the predicted forced expiratory volume in $1 \mathrm{sec}\left(\mathrm{FEV}_{1}\right)$ after $10 \mathrm{hr}$, and in $100 \%$ of the predicted maximum midexpiratory flow (MMEF) after 20

From the Division of Allergy and Clinical Immunology, Jefferson Medical College, Thomas Jefferson University; and the Children's Heart Hospital of Philadelphia, Philadelphia, Pennsylvania.

Send correspondence and requests for reprints to Herbert C. Mansman, Jr., MD, Division of Allergy and Clinical Immunology, Jefferson Medical College, Philadelphia, PA 19107 
$\mathrm{hr}$, whereas these parameters remained abnormal after 5 days when therapy was started $90 \mathrm{hr}$ after the onset of symptoms. Also, a 10-year evaluation of a self-referral emergency admission service for patients known to suffer from life-threatening asthma appears to have reduced the frequency of sudden unexpected death at home. ${ }^{5}$

An increase of $167 \%$ in the number of children admitted to the hospital in a region of London between 1970 and 1978 has been reported. ${ }^{6}$ There was a more than fivefold increase in self-referrals, and a higher readmission rate for these patients. It was suggested that this indicates an inadequacy of ambulatory care. Yet, during a staff development period the Children's Hospital of Pittsburgh (CHPgh) had shown a similar increase with a doubling of admissions between 1958 and 1968, ${ }^{7}$ even with a significant increase in the quality of the primary care provided these patients. At the Children's Hospital of Los Angeles, with an established training program, between 1969 and 1976 the number of admissions for asthma ranged between 408 and 595 with no significant increase and no significant change in the number requiring the intensive care unit, being between $0.7 \%$ and $1.9 \%$ of the status group. ${ }^{8}$ Thus, it should be obvious that the background of the unit reporting is essential to the interpretation applied to the results in this multifactorial situation.

The purpose of this chapter is to review the issues involved in the decisionmaking process that are likely to prevent the progression of acute severe asthma to early and then advanced status asthmaticus with acute respiratory insufficiency or with acute respiratory failure and then death. The data selected for this review have been mostly obtained from the pediatric literature because this issue is devoted to problems in children. Selected adult data are utilized where pediatric data are lacking. However, it is essential that the reader realize that certain therapeutic modalities must be used with great care in adults.

\section{Incidence}

The true incidence of status asthmaticus is unknown for several reasons: (1) the absolute number of asthmatic children in a community served by a pediatric facility is unknown and varies for many reasons, (2) the criteria for the diagnosis are not uniform, (3) the number of medications a patient might receive before arrival in the emergency room varies between none to seven or eight, (4) previous data are difficult to use because some facilities, like the CHPgh, had no multidisciplinary intensive care units (ICUs) until 1967 yet had an emergency room holding area, and (5) most general hospital pediatric facilities always have empty beds, whereas others like CHPgh rarely do.

The occurrence of status asthmaticus is impossible to describe without a uniformly accepted definition. Therefore, most authors have neglected this subject and have limited their data to those for patients with life-threatening asthma. The most helpful data are for the month of May 1979 at the Children's Hospital National Medical Center in Washington, D.C. (CHNMC). ${ }^{9}$ This is a long-established center with a stable inner-city clinic as well as a significant private patient population.

Previous to 1965 , it was generally the patient unresponsive to three injec- 
tions of epinephrine who was diagnosed as having status asthmaticus. Most children were not receiving around-the-clock therapy with theophylline. Now most of our patients have already received theophylline when first seen, ${ }^{10}$ as had $67 \%$ of the CHNMC patients. ${ }^{9}$ Interestingly, $23 \%$ of the known asthmatics had no medication prescriptions. Not infrequently patients are admitted with acute severe asthma after running out of medication or have recently stopped taking it. If unresponsiveness to a series of three epinephrine injections $(0.01$ $\mathrm{mg} / \mathrm{kg}$ every $20 \mathrm{~min}$ ) is the major criterion for the diagnosis of status asthmaticus, both with and without prior theophylline administration, then $24 \%$ of acutely ill patients are likely to be admitted based on the CHNMC study. At LaRabida Children's Hospital, the unresponsive group was $23 \%$ of those coming to the emergency room. ${ }^{11}$ This therapy differed from that at the CHNMC in that epinephrine was alternated with either isoproterenol or isoetharine by ultrasonic nebulization, with a mean of 4.7 such treatments before admission.

\section{Risk Factors and Predictive Indexes}

Most pediatric allergists agree that the risk profiles in childhood status asthmaticus should include males with severe or chronic disease, asthma since infancy, sudden changes in pattern, repeated episodes of status asthmaticus, barrel-chest deformity, short stature, underweight, steroid dependency, and poor coping style. ${ }^{12}$ In addition to these, the following have also been suggested: previous failure of usually effective therapy and short-term drug relief of symptoms. Thus, the occurrence of these characteristics suggests the need for very careful observation during each episode. ${ }^{13}$

A definition of status asthmaticus should identify those at risk who will require hospitalization for intense monitoring and comprehensive therapy. Yet, a list of criteria and/or definitions is no substitute for sound clinical judgment based on previous experience with an individual patient and his or her family. Moreover, careful, frequent observations over several hours is the best way to prevent advanced status asthmaticus as well as to identify patients who might need ventilatory support. ${ }^{14}$ A patient seen early in his attack will have a $\mathrm{PaCO}_{2}$ below $33 \mathrm{mmHg}$ and will be at low risk (11\%) of subsequent $\mathrm{PaCO}_{2}$ elevation. For those with a $\mathrm{PaCO}_{2}$ in the normal range, the risk of progression to respiratory failure is $40 \%$. Nine percent require immediate intubation. In a study on 445 adults in an ICU, two types of asthmatics not at risk were described: (1) no change in the $\mathrm{PaCO}_{2}$ level and no hypercarbia (41\%), and (2) initial hypercarbia that did not persist (17\%). Two types of at-risk asthmatics were seen: (1) fluctuating $\mathrm{PaCO}_{2}$ with frequent hypercarbia (14\%), and (2) $\mathrm{PaCO}_{2}$ increasing and hypercarbia persisting (29\%). These authors have suggested the use of the terms "early status asthmaticus" and "advanced status asthmaticus."

Another predictive index is the heart rate. While sinus tachycardia is commonly attributed to drug therapy, this may be an error because tachycardia greater than 110 beats/min indicates a severe episode and often subsides when the attack is brought under control with more vigorous drug therapy. ${ }^{15} \mathrm{De}-$ termination of the pulse rate is an excellent procedure that should be taught 
to parents for use at home. For years we have suggested measurement of sleeping respiratory rates to help parents judge the severity of respiratory illnesses.

Many emergency rooms have been using pulmonary function screening tests to judge the severity of respiratory diseases. The peak expiratory flow rate (PEFR), measured with a mini-Wright peak flow meter, and the forced expiratory volume in $1 \mathrm{sec}\left(\mathrm{FEV}_{1}\right)$ have been shown to have excellent correlation at various stages of treatment of acute asthma in adults. Thus, the PEFR may be substituted for the $\mathrm{FEV}_{1}$ in the emergency room. ${ }^{16}$

Martin et al. suggested that the PEFR might be used to screen those suspected of needing arterial blood gases (ABG), because there was a small but significant correlation between ABG parameters and the PEFR. No adult patients with a PEFR of greater than $25 \%$ of the predicted normal value had a $\mathrm{PaCO}_{2}$ greater than $45 \mathrm{mmHg}$ or a pHa less than 7.35. These authors felt that ABG parameters could thus be eliminated in at least $40 \%$ of patients with acute asthma. Such data may not be applicable to children for two reasons: (1) There may be significant metabolic acidosis, and (2) some asthmatic children have a higher actual PEFR than predicted, and the determined value may be significantly lower than $25 \%$ of the "best value" but higher than $25 \%$ of the predicted value.

One of the best predictive index systems has recently been described for adults. ${ }^{18}$ One point was given for each of the following presenting factors: pulse rate $\geqslant 120 / \mathrm{min}$, respiratory rate $\geqslant 30 / \mathrm{min}$, pulsus paradoxus $\geqslant 18 \mathrm{mmHg}$, PEFR $\leqslant 120$ liters/min, moderate to severe dyspnea, accessory-muscle use, and wheezing. The index scores of the admitted group $(5.1 \pm 1.0)$ and the relapse group $(4.9 \pm 1.0)$ were statistically significantly worse $(p<0.001)$ than those of the group treated successfully in the emergency room. This system has the advantage of being less subjective than most other scoring systems reported in the literature. In our hands, the other systems lost their accuracy with changes in shifts or nurses and/or house staff. Even when obtained and recorded hourly, such scores are a poor substitute for frequent, 30- to 60-min observations by a concerned, experienced physician.

\section{Epinephrine}

Epinephrine remains the drug of choice in the early treatment of acute bronchial asthma. Aqueous epinephrine, 1:1000, contains $0.01 \mathrm{mg}(10 \mu \mathrm{g})$ per 0.01 $\mathrm{ml}$. The usual dose is $0.01 \mathrm{mg} / \mathrm{kg}$, maximum $0.2 \mathrm{ml}$, which may be repeated twice, 20 min apart. ${ }^{19}$ Although this dose has been used for over 20 years, more recently supportive data have scientifically documented its efficacy.

Because this issue contains an article on $\beta$-adrenergic agents used in asthma, emphasis will be limited fundamentally to personal opinions about their use in status asthmaticus. During history taking specific questions must be asked about medications used to control asthma at home. While this is now especially true in regard to long-acting theophylline preparations, it must also become true of aerosolized bronchodilators. Although abuse of the longeracting new agents seemed less likely to occur, abuse of salbutamol (albuterol) has already been reported. ${ }^{20}$ 
Considerable clinical experience has been gained over the past 20 years with the routine use of epinephrine suspension, 1:200 (Sus-Phrine), in a dose of $0.005 \mathrm{ml} / \mathrm{kg}$ at 8 - to $12-\mathrm{hr}$ intervals by subcutaneous injection, with a maximum single dose of $0.2 \mathrm{ml} .{ }^{19}$ We have occasionally used it every $6 \mathrm{hr}$. This eliminates the trauma of frequent injections in children. Because $20 \%$ of this preparation is in an aqueous state for immediate utilization and the remainder is slowly dissolved, this is an excellent way to obtain both instantaneous and sustained relief of bronchospasm. If used initially in place of aqueous epinephrine and insufficient relief (less than 50\%) is observed in $30 \mathrm{~min}$, one dose of aqueous epinephrine, 1:1000, can also be given. We use the suspension most often as a replacement for the third dose of epinephrine.

Adults with acute asthma randomly treated with a subcutaneous injection of $0.1,0.3$, or $0.5 \mathrm{mg}$ epinephrine in a double-blind fashion had no significant difference in the PEFR among the three doses at 10, 20, and $40 \mathrm{~min}$. Yet, there was a significant difference at each time point. ${ }^{21}$ Why give more, when less works just as well? In a similar open study, randomly selected adults received three repeated doses of $0.1,0.3$, or $0.5 \mathrm{mg}$ epinephrine at 20-min intervals. In these more severely ill patients the $0.1-\mathrm{mg}$ initial dose resulted in no significant improvement, but this effect was overcome with statistically significant improvement occurring after each additional dose. ${ }^{22}$ There was no apparent advantage to the 0.5 - $\mathrm{mg}$ dose; it appears that the best dose is 0.3 $\mathrm{mg}$, to minimize side effects.

In a randomized, double-blind placebo control study, adults with acute asthma received one of two regimens: Three injections of $0.3 \mathrm{ml}$ of $1: 1000$ epinephrine at 20 -min intervals $(0.9 \mathrm{mg}$ epinephrine) plus an aerosol placebo every $10 \mathrm{~min}$ six times or three placebo injections at 20 -min intervals plus a single inhalation of epinephrine aerosol $(0.16 \mathrm{mg} / \mathrm{puff})$ every $10 \mathrm{~min}$ for 6 doses ( $0.96 \mathrm{mg}$ epinephrine). Although the mean data showed no statistical difference at the end of $1 \mathrm{hr}$, there was a definitely superior response to the injected epinephrine in a small subset with a PEFR of $\leqslant 120(p<0.005$ at 60 $\min ) .^{23}$

In another study 20 children were treated for acute asthma with terbutaline. There was a $50 \%$ increase in the PEFR $5 \mathrm{~min}$ after the injection, with an increase of $90 \% 30 \mathrm{~min}$ after treatment. ${ }^{24} \mathrm{~A}$ dose of $0.01 \mathrm{ml} / \mathrm{kg}$, with a maximum of $0.25 \mathrm{ml}$, has been recommended and may be repeated in $20 \mathrm{~min}$. The response has lasted as long as $4-5 \mathrm{hr}$. Yet this response, except for the duration, was similar to that to epinephrine. In a prospective single-dose, double-blind study in children with acute asthma 3,6 , or $12 \mu \mathrm{g} / \mathrm{kg}$ of terbutaline sulfate was compared with $10 \mu \mathrm{g} / \mathrm{kg}$ of subcutaneous epinephrine. Terbutaline was not significantly more effective at the $12 \mu \mathrm{g} / \mathrm{kg}$ dose, but it caused clinically imperceptible tremors, whereas this dose of epinephrine produced unpleasant headaches and excitation in a few patients. ${ }^{25}$

\section{Additional Recommendation}

Any child who has required epineprhine by subcutaneous injection 2 days in succession should be admitted to the hospital to receive more aggressive medical care. 


\section{Sodium Bicarbonate}

By the early 1960s it had become increasingly apparent that techniques were being developed to assess the acid-base balance of those in acute respiratory failure more accurately and conveniently. With the developments in open heart surgery came life support systems not previously available. Before then life-threatening asthma was treated with rectal ether and a touch of empirical sodium lactate. Our first patient who required controlled ventilation caused us to think seriously about control of metabolic and respiratory acidosis.

The magnitude of the problem seemed tremendous. A decrease of 0.3 of a pH unit, that is, a drop from 7.4 to 7.1, represents a doubling of the hydrogen ion concentration. The only experience, largely without adequate or frequent monitoring of $\mathrm{pHa}, \mathrm{PaO}_{2}$ and $\mathrm{PaCO}_{2}$, was during cardiopulmonary resuscitation (CPR). Sodium bicarbonate $\left(\mathrm{NaHCO}_{3}\right)$ was being used with increasing frequency, often on an empirical basis.

In 1964 the CHPgh group was using and recommending sodium lactate, and in $1965 \mathrm{NaHCO}_{3}$, to correct metabolic acidosis when the pHa was below $7.2 .{ }^{26}$ While this seemed reasonable at the time, there were during the next 2 years three patients who required controlled ventilation even after this regimen. ${ }^{27}$ By 1967 our protocol had been changed to the following: " $2 \mathrm{mEq}$ / $\mathrm{kg}$ over 5 minutes and repeat this amount more slowly during the next 45 minutes. If the hourly $\mathrm{pHa}$ is less than 7.35 and the $\mathrm{Na}$ less than $145 \mathrm{mEq} /$ $\mathrm{L}$, the $\mathrm{NaHCO}_{3}$ should be repeated hourly, as above, if necessary."19

The use in adults of $88 \mathrm{mEq}$ of $\mathrm{NaHCO}_{3}$ was first reported in 1965 after it was given to an epinephrine-unresponsive, aminophylline-treated, unconscious known asthmatic with a pHa of 6.91 and a $\mathrm{PaCO}_{2}$ of $150 \mathrm{mmHg}$. ${ }^{28}$ Within 10 min the patient was conscious, with a pHa of 7.10 and a $\mathrm{PaCO}_{2}$ of $95 \mathrm{mmHg}$. Following an additional $88 \mathrm{mEq}$ and without additional bronchodilator, the patient had a pHa of 7.37 and a $\mathrm{PaCO}_{2}$ of $48 \mathrm{mmHg}$, after 2 hr. A second patient, as seriously ill, also responded within $8 \mathrm{hr}$. Controlled ventilation was not used for either patient.

Karetzky and Mithoefer also measured sodium and bicarbonate excretion by the kidney following $\mathrm{NaHCO}_{3}$ infusion. ${ }^{29}$ Wide variation among individual patients was recorded. The type of response appeared unpredictable, because of multiple variables. This group of three patients was too small to assess the significance of delayed excretion in one patient.

Six more cases were reported later by this group, including the recovery of a 12-year-old with a pHa of 6.66 and a normal lactic acid concentration of $1.3 \mathrm{mEq} / \mathrm{liter} .^{30}$ In two of the patients artificial respiration was avoided by correction of acidemia. Two of the patients had associated congestive heart failure, which was not adversely affected by a total dose of 88 and $352 \mathrm{mEq}$ of $\mathrm{NaHCO}_{3}$, respectively. The bronchospasm in the former responded without the use of a bronchodilator.

Administration of $\mathrm{NaHCO}_{3}, 50-100 \mathrm{mEq}$, to mild asthmatics usually responding to only a single dose of epinephrine resulted in no significant improvement in the $\mathrm{FEV}_{1}$, although most patients reported slight relief. ${ }^{31}$ Yet there was a significant decrease $(p<0.01)$ in the $\mathrm{PaO}_{2}(2-22 \mathrm{mmHg}$, mean 
$9.7 \mathrm{mmHg}$ ). The $\mathrm{pH}$ increased by a mean of 0.06 units (range $0-0.12$ ). Yet, this study, although apparently prospective, lacked controls and crossover data with a placebo and epinephrine alone. Nonetheless, it is obvious that $\mathrm{NaHCO}_{3}$ should be given only if the patient is receiving $\mathrm{O}_{2}$.

A dose of $2.5 \mathrm{mEq} / \mathrm{kg}$ of $\mathrm{NaHCO}_{3}$ was found to be sufficient to maintain the $\mathrm{pHa}$ for $30 \mathrm{~min}$ in dogs made apneic and with ventricular fibrillation for 5 min, followed by CPR ${ }^{32}$ The short duration of the effect suggested the need for more $\mathrm{NaHCO}_{3}$ after CPR.

Another experimental model was also evaluated by the CHPgh group. In vitro acidosis had a profound effect on the ability of epinephrine and aminophylline to relax guinea pig tracheal smooth muscle, but this effect was almost instantaneously reversed with a conversion of the $\mathrm{pH}$ from 7.0 or 7.2 to $7.4 .^{33,34}$

Additional clinical studies at CHPgh between 1968 and 1971 have emphasized the need for "vigorous pHa control" with the use of oxygenation and $\mathrm{NaHCO}_{3} \cdot{ }^{35}$ During a prior 4-year period with a low dose or no $\mathrm{NAHCO}_{3}$, intubation and controlled ventilation were necessary in $2.6 \%$ of patients with status asthmaticus, whereas later with vigorous early normalization of $\mathrm{pHa}$, the incidence was only $0.6 \%$. The dose used was $1-2 \mathrm{mEq} / \mathrm{kg}$ body weight intravenously over $5 \mathrm{~min}$ with a repeat dose within 10-15 minutes if wheezing persisted. In severe status asthmaticus these two doses were given empirically without a waiting blood gas data, although determinations were available in the ICU. Subsequent $\mathrm{NaHCO}_{3}$ titration was utilized to restore and to maintain the $\mathrm{pHa}$ between 7.4 and 7.45. During 1970, 11 patients with advanced status asthmaticus received $4-13 \mathrm{mEq} / \mathrm{kg}$ during the first $6 \mathrm{hr}$ (mean $8 \mathrm{mEq} / \mathrm{kg}$ ). Two of these patients with pulmonary infection and inspissated secretions required controlled ventilation.

Several complications deserve mention. Death occurred in one patient because she was receiving inadequate therapy. Hypokalemia always occurred when the dose was greater than $3 \mathrm{mEq} / \mathrm{kg} / 6 \mathrm{hr}$. This was corrected by adding potassium chloride $(\mathrm{KCl})$ to the intravenous fluids. When more than $8 \mathrm{mEq} /$ $\mathrm{kg} / 6 \mathrm{hr}$ was given, up to $60 \mathrm{mEq} / \mathrm{liter}$ of $\mathrm{KCl}$ was necessary. Hypernatremia was mild and transient and occurred only when more than $8 \mathrm{mEq} / \mathrm{kg} / 6 \mathrm{hr}$ was required. The highest serum sodium level was $155 \mathrm{mEq} /$ liter, and it returned to 146 within $5 \mathrm{hr}$. Hypocalcemia was slight and did not require replacement therapy. Hyperosmolality occurred in patients who received more than $10 \mathrm{mEq} / \mathrm{kg} / 6 \mathrm{hr}$, but was slight. Severe alkalemia was avoided by careful titrations and frequent $\mathrm{pHa}$ determinations. All $\mathrm{PaCO}_{2}$ values obtained 15-20 min after $\mathrm{NaHCO}_{3}$ administration were lower than the initial values, yet earlier hypercarbia because of $\mathrm{NaHCO}_{3}$ was not evaluated. Moreover, the use of $\mathrm{NaHCO}_{3}$ continues to be credited by this group, since the incidence of mechanical ventilation has remained at $0.6 \%$ for 10 years and intravenous isoproterenol has not been used for any of the patients. ${ }^{36}$

After 12 years at CHPgh I moved in 1968 to Jefferson Medical College (JMC). This component of the protocol for the treatment of status asthmaticus has remained unchanged. An additional large service, not as large as that at the CHPgh, is different in that we have had for 11 years a chronic asthma 
care program at the Children's Heart Hospital ( $\mathrm{CHH}$ ) with a daily census of 25-30 intractable asthmatic children. Many of these patients previously required intravenous isoproterenol and/or controlled ventilation, and a few, several times. During this 14 -year period, none has required intravenous isoproterenol, and in 1982 the first child required controlled ventilation, essentially because of inattention to the $\mathrm{NaHCO}_{3}$ regimen. Moreover, there has not been an in-hospital death because of status asthmaticus with this service in 25 years, ${ }^{37}$ a fact I have been very hesitant to publish.

In addition to the previously cited uncontrolled observations, good data on the efficacy of $\mathrm{NaHCO}_{3}$ in controlling pHa have appeared. In evaluating the role of hydrogen ion in the production of exercise-induced asthma, six asthmatics were exercised to exhaustion. All subjects developed significant acidemia, which was most extreme 4-5 min after the completion of exercise ( $\mathrm{pHa}$ 7.29). This decrease in $\mathrm{pH}$ was completely eliminated by the infusion of a $1 \mathrm{mEq} / \mathrm{ml}$ solution of $\mathrm{NaHCO}_{3}$ in amounts based on the calculated decreases in $\mathrm{HCO}_{3}$ in the first experiment and estimates of the size of the extracellular fluid compartment based on body weight. The mean dose was $178 \pm 36(\mathrm{SD}) \mathrm{mEq}$, or $2.96 \mathrm{mEq} / \mathrm{kg}$ assuming an average adult weight of $60 \mathrm{~kg} .{ }^{38}$

Many pediatricians are rightly concerned about the use of $\mathrm{NaHCO}_{3}$ as a rapid hypertonic $(1.0 \mathrm{M})$ intravenous infusion into neonates with respiratory distress syndrome..$^{39,40}$ The complications seen in infants have not been found in patients with asthma. There may be only a relatively "closed system" in asthmatics, in that the nonmetabolic increase in $\mathrm{CO}_{2}$ can be rapidly eliminated as illustrated by the CHPgh studies. ${ }^{35}$ Moreover, in asthma a slow infusion of a 2:3 isotonic infusion (isotonic $=3 \mathrm{mEq} / \mathrm{kg}$ ) is given instead of a rapid infusion of hypertonic $\mathrm{NaHCO}_{3}$ as is given to infants.

However, the use of $\mathrm{NaHCO}_{3}$ has received wide acceptance in the pediatric allergy literature by directors of established training centers. Most agree that, when the pHa is below 7.3 and the base deficit is greater than $5 \mathrm{mEq} / \mathrm{iter}$, $\mathrm{NaHCO}_{3}$ is recommended. The aim is to restore the extracellular $\mathrm{pHa}$ to 7.35-7.45. Therefore, the following formula is based on the assumption that the extracellular fluid space represents $30 \%$ of body weight:

Amount of $\mathrm{NaHCO}_{3}$ in $\mathrm{mEq}$ to give $=$ amount of negative base excess $\times$ $30 \%$ of body weight in $\mathrm{kg}$.

This recommendation received only mild endorsement by the Section on Allergy and Immunology of the American Academy of Pediatrics in a statement that it "may be helpful" to correct the metabolic component of the acidosis. ${ }^{41} \mathrm{My}$ recommendation remains unchanged: up to $4 \mathrm{mEq} / \mathrm{kg} / \mathrm{hr}$ if the $\mathrm{pHa}$ is less than 7.35.

While it has been recommended that patients who require alkalization should be admitted to the hospital, ${ }^{35}$ our service has had extensive experience with the use of $\mathrm{NaHCO}_{3}$ in the emergency room. Some patients need to be admitted, but many have been discharged. $\mathrm{NaHCO}_{3}$ was not used early with a pHa between 7.35 and 7.3 in the emergency room studies reported in the section on incidence. ${ }^{9,11,18}$ 
Table 1. Intravenous Dosing With Theophylline in Children

\begin{tabular}{|c|c|c|}
\hline $\operatorname{Dose}^{a}$ & Without serum levels & With serum levels \\
\hline $\begin{array}{l}\text { Loading dose (over a } 20 \text {-min perio } \\
\text { Oral theophylline within } 6 \mathrm{hr} \\
\text { No previous theophylline }\end{array}$ & $\begin{array}{l}2 \mathrm{mg} / \mathrm{kg}^{b} \\
4 \mathrm{mg} / \mathrm{kg}\end{array}$ & $\begin{array}{l}3-5 \mathrm{mg} / \mathrm{kg} \\
6 \mathrm{mg} / \mathrm{kg}\end{array}$ \\
\hline $\begin{array}{l}\text { Maintenance dose } \\
\text { Continuous infusion }\end{array}$ & $0.75 \mathrm{mg} / \mathrm{kg} / \mathrm{hr}$ & $0.8-1.25 \mathrm{mg} / \mathrm{kg}$ \\
\hline $\begin{array}{l}\text { Maximum dose (if clinically unresf } \\
\text { For } 1-6 \mathrm{hr} \\
\text { Dose not to exceed }\end{array}$ & $\begin{array}{c}1 \mathrm{mg} / \mathrm{kg} / \mathrm{hr} \\
22 \mathrm{mg} / \mathrm{kg} / 24 \mathrm{hr}\end{array}$ & $28 \mathrm{mg} / \mathrm{kg} / 24 \mathrm{hr}$ \\
\hline
\end{tabular}

\section{Theophylline}

Another article in this issue is devoted to theophylline, but I will comment on my experience and my interpretation of the relevant literature.

Since $1960 \mathrm{CHPgh}$ patients with status asthmaticus have received $4 \mathrm{mg} / \mathrm{kg}$ of aminophylline every $6 \mathrm{hr}$ by constant intravenous infusion. ${ }^{26,35}$ After 1968 some received it every $4 \mathrm{hr}$. JMC patients received this constant infusion, 4 $\mathrm{mg} / \mathrm{kg}$ of aminophylline, every $6 \mathrm{hr}$, but in 1968, $2 \mathrm{mg} / \mathrm{kg}$ as a loading dose was added to the regimen if no theophylline had been taken previously. Moreover, a very sick child was often treated with $1 \mathrm{mg} / \mathrm{kg} / \mathrm{hr}$ for several hours. ${ }^{19}$ The efficacy of aminophylline was confirmed by a double-blind trial reported in $1971 . .^{42}$ In 1973 the JMC protocol was changed to include a loading dose of $4 \mathrm{mg} / \mathrm{kg}$ if none had been taken and retained in the previous $6 \mathrm{hr}$, followed by a continuous infusion of $4 \mathrm{mg} / \mathrm{kg}$ over each 6-hr period (up to $20 \mathrm{mg} / \mathrm{kg} / 24 \mathrm{hr}$ ). In 1976 the JMC protocol was changed again with the introduction of the availability of serum theophylline concentration determinations. Although the previous dose was encouraged, a loading dose of $5.6 \mathrm{mg} /$ $\mathrm{kg}$ was permitted when the serum level was determined. A maintenance dose of $1.25 \mathrm{mg} / \mathrm{kg} / \mathrm{hr}$ could then be used provided steady state levels were obtained every 6-12 hr. Based on clinical experience, in 1978 the doses were slowly elevated as illustrated in Table 1 . It should be noted that these doses are slightly less than current recommendations of others, ${ }^{41}$ because it is easier to increase the dose than to decrease it. This drug is much too important to permit overdosing to place it back on the shelf again, since letters to the editor that correct recommendations receive scant attention. ${ }^{43}$ At this time, the dosing requirements for our patients were placed on $3 \times 5$ cards after each acute episode, an excellent immediately available resource for dosing. ${ }^{44}$

\section{Corticosteroids}

There is an article on corticosteroids in this issue, and accordingly I will relate only my use of steroids and its rationale. For several years at JMC, $7 \mathrm{mg} / \mathrm{kg}$ of body weight ${ }^{45}$ of hydrocortisone sodium succinate (Solu-Cortef) was given 
when steroids had been previously required, when an attack was very severe, when the $\mathrm{PaO}_{2}$ was less than $60 \mathrm{mmHg}$, or when the patient had not significantly improved after treatment with the above regimen within $6 \mathrm{hr}$. This was followed by $4 \mathrm{mg} / \mathrm{kg}$ every $4 \mathrm{hr}$. Occasionally a very sick patient received it every $2 \mathrm{hr}$ to provide a serum level of $150 \mu \mathrm{g} / \mathrm{ml} .{ }^{46} \mathrm{The}$ CHPgh used $5 \mathrm{mg} /$ $\mathrm{kg}$ body weight of hydrocortisone repeated every $6 \mathrm{hr}$ or methylprednisolone at a dose of $1 \mathrm{mg} / \mathrm{kg} / 6 \mathrm{hr} .^{35}$

Over the past few years, several observations have caused the regimen to be changed. As sicker asthmatics entered the $\mathrm{CHH}$, more had received steroids recently and most were sicker, having a decreased $\mathrm{PaO}_{2}$ during status asthmaticus. The implication of the observation of significantly higher $\mathrm{PaO}_{2}$ values in patients treated with corticosteroids also was of influence..$^{45}$ The first change was more rapid administration to avoid the risk of prolonged hypoxemia. Corticosteroids can always be discontinued in $12-48 \mathrm{hr}$ without problems.

The second major change has been the gradual replacement of hydrocortisone by methylprednisolone sodium succinate (Solu-Medrol). Substitutes are not permitted, because Solu-Medrol is known to be paraben-free, while many generic substitutes are not. This change came about because of the need to use larger doses of steroids and the occurrence of water retention in several patients on maintenance fluids. Methylprednisolone is known to have much less tendency to induce sodium and water retention.

In adults, 3 days of treatment with methylprednisolone, $125 \mathrm{mg}$ every 6 $\mathrm{hr}$, appears adequate for most refractory asthmatics. Some patients relapse when the dosage is tapered over the next several days. ${ }^{47} \mathrm{~A}$ double-blind randomized study of the use of methylprednisolone in status asthmaticus showed that $125 \mathrm{mg}$ every $6 \mathrm{hr}$ elicited statistically significant improvement in indexes over the low dose ( $15 \mathrm{mg}$ every $6 \mathrm{hr}$ ) on all 4 days $(p<0.01)$ and better improvement than the medium dose (40 mg every $6 \mathrm{hr})$ on day $1(p<$ $0.05){ }^{48}$ Yet there was no apparent advantage to the use of extremely high doses $\left(300 \mathrm{mg} / \mathrm{m}^{2}\right)$ every $6 \mathrm{hr}$ in a small group of children of which only $10 \%$ were at risk of developing advanced status asthmaticus. ${ }^{49}$

\section{Current Recommendations}

Upon admission Solu-Medrol (methylprednisolone sodium succinate), $2 \mathrm{mg} /$ $\mathrm{kg}$ body weight, should be given intravenously slowly over $10 \mathrm{~min}$ and $1 \mathrm{mg} /$ $\mathrm{kg}$ every $6 \mathrm{hr}$. In severe cases (advanced status asthmaticus), $4 \mathrm{mg} / \mathrm{kg}$ followed by $2 \mathrm{mg} / \mathrm{kg}$ body weight should be given every $6 \mathrm{hr}$ for $24-48 \mathrm{hr}$.

\section{The Role of Oxygen Therapy}

Although it is natural to anticipate a low $\mathrm{PaO}_{2}$ during acute asthma, a review of the literature on subclinical asthma ${ }^{50}$ revealed that significant hypoxemia occurs in relatively normal asthmatic children. Such patients are likely to become more hypoxemic during sleep and status asthmaticus. Essential to the vigorous control of $\mathrm{pHa}$ is the attempt to prevent acidosis induced by tissue anoxia. In order to do this, humidified $50-100 \%$ oxygen is recommended ${ }^{35}$ 
(it takes $6-12 \mathrm{hr}$ of $100 \% \mathrm{O}_{2}$ to damage the lungs). At JMC every effort is made to maintain a $\mathrm{PaO}_{2}$ between 80 and $100 \mathrm{mmHg}$, and $\mathrm{O}_{2}$ delivery is initiated almost immediately.

\section{Hydration}

While the likelihood of dehydration in ill children is great for many reasons, ${ }^{19}$ the fluid deficit should be replaced with care. Both hypovolemia, a reported complication of status asthmaticus, ${ }^{51}$ and a significant increase in pulmonary blood volume ${ }^{52}$ and pulmonary edema must be avoided..$^{53}$ Patients should be encouraged to ingest fluids at home to minimize dehydration. The occurrence of markedly negative mean pleural pressures in severe asthma raises questions about fluid intake. An increase in microvascular hydrostatic pressure with a decrease in plasma colloid osmotic pressure favors pulmonary edema. ${ }^{53} \mathrm{More}$ over, peribronchial cuffs of edema can lead to airway narrowing with increases in airway resistance and a tendency to premature airway closure. ${ }^{54}$ Prolonged wheezing and pulmonary congestion occasionally follow status asthmaticus. Fluid restriction and spontaneous and/or induced diuresis have been followed by improvement in such patients.

Elevated plasma concentrations of antidiuretic hormone $(\mathrm{ADH})$ have been reported in all of seven acutely and severely ill asthmatics, aged 6-52 years. ${ }^{55}$ In each the ADH fell upon recovery. Therefore, care must be taken to avoid water intoxication during status asthmaticus. Patients must be observed carefully for a change in mental state, even though the chest symptoms have been alleviated. Although anoxia, hypercarbia, and theophylline toxicity must be ruled out, the occurrence of hyponatremia with a low serum osmolarity, a high urine osmolarity, and an elevated urinary sodium level would confirm the diagnosis. One cause of the elevated $\mathrm{ADH}$ could be $\beta$-adrenergic stimulation, because increases in $\mathrm{ADH}$ have followed administration of $0.03-0.06$ $\mu \mathrm{g} / \mathrm{kg} / \mathrm{min}$ of isoproterenol by infusion. The effect was blocked by the $\beta$ blocker propranolol. ${ }^{56}$

\section{Intravenous Adrenergic Agents}

Because of the complications of controlled ventilation in apparently medically irreversible status asthmaticus, the Children's Hospital of Philadelphia group (CHPhil) introduced the use of intravenous isoproterenol infusion. ${ }^{57,58}$ Another large series has been reported from Denver. ${ }^{59}$ The reader is referred to these three references for techniques and comprehensive discussions, because the decision to utilize this technique must not be taken lightly and should be made only by experienced personnel in an ICU where continuous cardiac monitoring and controlled ventilation are possible. Ten percent of the 20 CHPhil patients required subsequent controlled ventilation. Seven of 27 (21\%) of the Denver patients were nonresponders and were successfully managed by mechanical ventilation. Interestingly, only $19 \%$ required mechanical ventilation before the introduction of intravenous isoproterenol in Denver.

It has been pointed out that a "cardinal advantage" of this technique is the short half-life of its cardiovascular effect (approximately $1 \mathrm{~min}$ ) and elevated 
blood levels (approximately $4 \mathrm{~min}$ ) in contrast to those of theophylline. ${ }^{58}$ Yet, all three of these reports detailed experiences before titering of theophylline dosage with serum concentrations was common.

Although there is little doubt that this procedure should be used in children before controlled ventilation, it is not without its own set of complications. Ventricular tachycardia (more than 200 beats $/ \mathrm{min}$ ) was immediately reversed upon discontinuation..$^{58}$ The Denver study described nodal tachycardia which reverted spontaneously in $\frac{1}{2} \mathrm{~min}$ to sinus tachycardia; and another patient developed acute mobilization of copious secretions during the infusion. Weaning may present a problem, because of rebound bronchospasm. Myocardial ischemia in a 14-year-old ${ }^{60}$ and fatal myocardial toxicity in an 18 -year-old ${ }^{61}$ have followed the use of intravenous isoproterenol.

Intravenous isoproterenol can cause a significant change in theophylline kinetics. An increase in theophylline clearance reverses when the isoproterenol is discontinued. ${ }^{62}$ These changes do not correlate with $\mathrm{pHa}$ changes.

Alternatives to isoproterenol have been suggested in periodic reports. Ten children with unresponsive advanced status asthmaticus received multiple injections of $0.01-0.04 \mathrm{mg} / \mathrm{kg}$ of terbutaline at $15-$ to 30 -min intervals. The mean cumulative dose was $3.1 \mathrm{mg}$ given in a mean of six doses over a mean duration of $7 \mathrm{hr}$. No cardiac arrhythmias occurred. One patient required controlled ventilation. ${ }^{63}$ Acute myocardial infarction was reported to have followed the administration of intravenous salbutamol in a 58-year-old patient, and others have cautioned about the use of isoproterenol in adults for this reason. ${ }^{59,64}$

The protocol used at the CHPgh and JMC differ from those used in the reports cited in this section. The most significant difference is the approach to vigorous $\mathrm{pHa}$ control with $\mathrm{NaHCO}_{3}$. At JMC controlled ventilation was used once, because a rapid turn of events prevented an adequate trial of $\mathrm{NaHCO}_{3}$ and isoproterenol. This was the only time in my 16-years of using this protocol that its vigorous enforcement failed. This record could not have been accomplished without a dedicated staff, initially at the CHPgh and later at JMC and $\mathrm{CHH}$.

\section{Controlled Ventilation}

The use of controlled ventilation with muscle paralysis in the treatment of children with status asthmaticus was first employed in the United States in 1964. .5, $26^{6}$ Since then several comprehensive reviews have appeared. ${ }^{27,66,67}$ Readers likely to use this procedure should review the references, since techniques have been described elsewhere. Fortunately, most pediatric house staffs become proficient in the use of ventilators during their neonatal rotations. Essential to the successful outcome of any procedure is a written protocol. Generally speaking, it is more important for the implementor to do what he or she does best, rather than to set down inflexible guidelines.

Established indications are the presence of three of the following: ${ }^{.7}$

1. Severe inspiratory retractions

2. Absence of inspiratory breath sounds

3. Generalized muscular weakness 
4. Decreased level of consciousness and response to pain

5. Cyanosis in $40 \%$ ambient oxygen

6. $\mathrm{A} \mathrm{PaCO}_{2}$ of $65 \mathrm{mmHg}$ or higher.

Yet, in the absence of obvious clinical deterioration, most of these patients respond to intensive medical therapy within $12 \mathrm{hr},{ }^{27} \mathrm{~A}$ rise in the $\mathrm{PaCO}_{2}$ of $10 \mathrm{mmHg} / \mathrm{hr}$ over two consecutive hours is an ominous sign.

Most practitioners sedate, oxygenate, proceed with nasotracheal intubation, paralyze, aspirate, connect to a volume-cycled ventilator, and set the ventilator for moderate hyperventilation, with the addition of a slight expiratory resistance to belp prevent airway collapse ${ }^{26}$ and with an initial tidal volume of $10 \mathrm{ml} / \mathrm{kg}$ body weight.

Continuation of the sedation for amnesia, paralysis to facilitate ventilation, and asthmatic medications is essential. Controlled ventilation in two children, not previously treated with intravenous isoproterenol, had no effect on theophylline clearance. ${ }^{62}$ Continuous observation by an experienced physician is mandatory. Complications have been extensively reported. ${ }^{59,68}$

If controlled ventilation is unsuccessful in adequately ventilating the patient, there are three alternatives. The most promising is the use of halothane. ${ }^{69}$ It successfully reversed status asthmaticus in an 11-month-old who was unresponsive to terbutaline, aminophylline, isoproterenol infusion, controlled ventilation with meperidine and pancuronium, and increasing doses of isoproterenol to a heart rate of 210 beats/min and blood pressure of 180/80 while on the ventilator. Halothane, $1 \%$ with $99 \%$ oxygen, was started by inhalation and in 10 min better aeration, increased chest movement, and increased wheezing (a good sign in this case) occurred. After $75 \mathrm{~min}$ of halothane, the patient had improved dramatically. The authors speculate that possibly the intubation could have been prevented if halothane had been used first. Halothane is known to be an excellent bronchodilator.

Bronchopulmonary lavage has been used successfully in adults with status asthmaticus, ${ }^{70}$ but it is a most difficult procedure.

Finally, extracorporeal membrane oxygenation might be considered. ${ }^{71}$

\section{Conclusion}

The essence of pediatrics is prevention. It is easier to prevent the need for each advance in treatment than it is to use that modality. It all begins by preventing status asthmaticus. ${ }^{50}$

\section{References}

1. Smith GJ: Leading causes of pediatric admissions in children's and general hospitals. PAS Reporter 12:7, 1974 (PAS Reporter, 1968 Green Road, Ann Arbor, MI 48105)

2. Mitchell EA, Elliott RB: Hospital admissions for asthma in children: A prospective study. NZ Med J 695:331-334, 1981

3. Annotation: Saving asthmatics. Br Med J 1:1520-1521, 1979

4. McFadden ER Jr: Respiratory mechanics in asthma, in Weiss EB, Segal MS (eds) Bronchial Asthma: Mechanisms and Therapeutics. Boston, Little Brown, 1976

5. Crompton GK, Grant IWB, Bloomfield P: Edinburgh Emergency Asthma Admission Service: Report on 10 years' experience. Br Med J 2:1199-1201, 1979 
6. Anderson HR, Bailey P, West S: Trends in the hospital care of acute childhood asthma 1970-8: A regional study. B Med J 281:1191-1194, 1980

7. Palm CR, Murcek MA, Roberts TR, Mansmann HC Jr, Fireman PA: A review of asthma admissions and deaths at Children's Hospital of Pittsburgh. J Allergy 46:257-269, 1970

8. Richards W, Lew C, Carney J, Platzker A, Church JA: Review of intensive care unit admissions for asthma. Clin Pediatr 18:345-352, 1979

9. O'Brien SR, Hein EW, Sly RM: Treatment of acute asthmatic attacks in a holding unit of a pediatric emergency room. Ann Allergy 45:159-162, 1980

10. Gawchik SM, McGeady SJ, Mansmann HC Jr: Relationship between response of bronchospasm to epinephrine and simultaneous theophylline levels. J Allergy Clin Immunol Suppl 67,1981

11. Lulla S, Newcomb RW: Emergency management of asthma in children. J Pediatr 97:346-350, 1980

12. Laurenzi GA: A clinician's view of status asthmaticus, including complications and mortality in bronchial asthma, in Weiss EB (ed): Status Asthmaticus. Baltimore, University Park Press, 1978

13. Reback AS: Characteristics of the risk patient and features of the prodrome state of status asthmaticus, in Weiss EB (ed): Status Asthmaticus. Baltimore, University Park Press, 1978

14. Henrich AE, Huang CT, Lyons HA: Status asthmaticus-Definition, criteria for diagnosis and clinical causes, in Weiss EB (ed): Status Asthmaticus. Baltimore, University Park Press, 1978

15. Rees HA, Millar JS, Donald KW: A study of the clinical course and arterial gas tensions of patients in status asthmaticus. Quart J Med 37:541-561, 1968

16. Nowak RM, Pensler MI, Sarkar DD, Anderson JA, Kvale PA, Ortiz AE, Tomlanovich MC: Comparison of peak expiratory flow and $\mathrm{FEV}_{1}$ admission criteria for acute bronchial asthma. Ann Emerg Med 11:64-69, 1982

17. Martin TG, Eienbaas RM, Pingleton SH: Use of peak expiratory flow rates to eliminate unnecessary arterial blood gases in acute asthma. Ann Emerg Med 11:70-73, 1982

18. Fischl MA, Pitchenik A, Gardner LB: An index predicting relapse and need for hospitalization in patients with acute bronchial asthma. N Engl J Med 305:783-789, 1981

19. Mansmann HC Jr: Management of the child with bronchial asthma. Pediatr Clin North Am 15:357-385, 1968

20. Pratt HF: Abuse of salbutamol inhalers in young people. Clin Allergy 12:203-208, 1982

21. Gotz IP, Brandstetter RD, Mar DD: Bronchodilatory effect of subcutaneous epinephrine in acute asthma. Ann Emerg Med 10:518-520, 1981

22. Karetzky MS: Acute asthma: The use of subcutaneous epinephrine in therapy. Ann Allergy 44:12-14, 1980

23. Pliss LB, Gallagher EJ: Aerosol vs injected epinephrine in acute asthma. Ann Emerg Med 10:353-355, 1981

24. Sly RM, Badiei B, Faciane J: Comparison of subcutaneous terbutaline with epinephrine in the treatment of asthma in children. J Allergy Clin Immunol 59:128-135, 1977

25. Simons FER, Gillies JD: Dose response of subcutaneous terbutaline and epinephrine in children with acute asthma. Am J Dis Child 135:214-217, 1981

26. Beam LR, Marcy JH, Mansmann HC Jr: Medically irreversible status asthmaticus in children. J Am Med Assoc 194:968-972, 1965

27. Mansmann $\mathrm{HC} \mathrm{Jr}$, March JH, Fine J: Controlled ventilation with muscle paralysis in status asthmaticus: A review of additional experiences obtained with three children. Ann Allergy 25:11-19, 1967

28. Mithoefer JC, Runser RH, Karetzky MS: The Use of sodium bicarbonate in the treatment of acute bronchial asthma. N Engl J Med 272:1200-1203, 1965

29. Karetzky MS, Mithoefer JC: The renal excretion of sodium and bicarbonate following $\mathrm{NaHCO}_{3}$ infusion in patients with respiratory acidosis. Am J Med Sci 254:851-854, 1967

30. Mithoefer JC, Porter WF, Karetzky MS: Indications for the use of sodium bicarbonate in the treatment of intractable asthma. Respiration 25:201-215, 1968

31. Milledge JS, Benjamin S: Arterial desaturation after sodium bicarbonate therapy in bronchial asthma. Am Rev Respir Dis 105:126-128, 1972 
32. Kirimli B, Harris LC Jr, Safer P: Evaluation of sodium bicarbonate and epinephrine in cardiopulmonary resuscitation. Anesth Analg (Cleve) 48:649-658, 1969

33. Ushinski SC, Mansmann HC Jr, Roberts J: The Effect of $\mathrm{pH}$ on the response of tracheal smooth muscle to epinephrine and histamine. Fed Proc 28:481, 1969

34. Ushinski SC, Mansmann HC Jr, Roberts J: The effect of acidosis on the response of tracheal smooth muscle to aminophylline and acetylcholine. Am Soc Pharm Exp Ther Pharmacol 11:277, 1969

35. Kampshulte S, Marcy J, Safer P: Simplified physiologic management of status asthmaticus in children. Crit Care Med 1:69-74, 1973

36. Fireman P: Status asthmaticus in children, in Allergy: Middleton E Jr, Reed CE, Ellis EF (eds): Allergy: Principles and Practice, St. Louis, C.V. Mosby, 1978

37. Mansmann HC Jr, McGeady SJ: A twenty year evolving protocol to prevent death during status asthmaticus. Pediatr Res 11:575, 1977

38. Strauss RH, Ingram RH, McFadden ER Jr: A critical assessment of the role of circulating hydrogen ion and lactate in the production of exercise-induced asthma. J Clin Invest 60:658-664, 1977

39. Ostrea EM, Odell GB: The influence of bicarbonate administration on blood $\mathrm{pH}$ in a "closed system": Clinical implications. J Pediatr 80:671-680, 1972

40. Eidelman AI, Hobbs JF: Bicarbonate therapy revisited. Am J Dis Child 132:847-848, 1978

41. Easton J, Hilman B, Shapiro G, Weinberger M: American Academy of Pediatrics, Section on Allergy and Immunology report: Management of asthma. Pediatrics 68:874-876, 1981

42. Pierson WE, Bierman CW, Stamm SJ, Van Arsdel PP Jr: Double-blind trial of aminophylline in status asthmaticus. Pediatrics 48:642-646, 1971

43. Weinberger M: Management of asthma-A correction. Pediatrics 69:663, 1982

44. Rooklin AR, Firth JR, Auritt WA, Hopkins LE, McGeady SJ, Mansmann HC Jr: Intrapatient variability of theophylline metabolism during repeated episodes of status asthmaticus. J Allergy Clin Immunol 65:178, 1980

45. Pierson WE, Bierman CW, Kelley VC: A double-blind trial of corticosteroid therapy in status asthmaticus. Pediatrics 54:282-288, 1974

46. Collins JV, Clark TJH, Harris PWR, Townsend J: Intravenous corticosteroids in treatment of acute bronchial asthma. Lancet 2:1047-1049, 1970

47. Krouse HA, Santiago SM, Klanstermeyer WB: Intravenously given methylprednisolone in refractory asthma. West J Med 132:106-110, 1980

48. Haskell RJ, Hansen JE: A double-blind randomized clinical trial of methylprednisolone in status asthmaticus. Chest $80: 377,1981$

49. Harfi H, Hanissian AS, Crawford LV: Treatment of status asthmaticus in children with high doses and conventional doses of methylprednisolone. Pediatrics 61:829-831, 1978

50. Mansmann HC Jr: The evaluation, control, and modification of continuing asthma. Clin Chest Med 1:339-360, 1980

51. Straub PW, Bühlmann AA, Rossier PH: Hypovolaemia in status asthmaticus. Lancet 2:923-926, 1969

52. Pierson RN Jr, Grieco MA: Pulmonary blood volume in asthma. J Appl Physiol 32:391-396, 1972

53. Stalcup SA, Mellins RB: Mechanical forces producing pulmonary edema in acute asthma. $\mathrm{N}$ Engl J Med 297:592-596, 1977

54. Millic-Emili J, Ruff F: Effects of pulmonary congestion and edema on the small airways. Bull Physiol Pathol Respir 7:1181-1196, 1971

55. Baker JW, Yeager S, Segar WE: Elevated plasma antidiuretic hormone levels in status asthmaticus. Mayo Clin Proc 51:31-34, 1976

56. Levi J, Coburn J, Kleeman CR: Mechanism of the antidiuretic effect of $\beta$-adrenergic stimulation in man. Arch Intern Med 136:25-29, 1976

57. Woods DW, Downes JJ, Scheinhopf $\mathrm{H}$, Lecks $\mathrm{HI}$ : Intravenous isoproterenol in the management of respiratory failure in childhood status asthmaticus. J Allergy Clin Immunol 50:75-81. 1972 
58. Downes JJ, Wood DW, Harwood I, Scheinkopf HN, Raphaelz RC: Intravenous isoproterenol infusion in children with severe hypercapnia due to status asthmaticus. Crit Care Med 1:63-68, 1973

59. Parry WH, Mantorano F, Cotton EK: Management of life-threatening asthma with intravenous isoproterenol infusion. Am J Dis Child 130:39-42, 1976

60. Matson JR, Loughlin GM, Strunk RC: Myocardial ischemia complicating the use of isoproterenol in asthmatic children. J Pediatr 92:776-778, 1978

61. Kurland G, Williams J, Lewiston NJ: Fatal myocardial toxicity during continuous infusion intravenous isoproterenol. J Allergy Clin Immunol 63:407-411, 1979

62. Hemstreet MP, Miles MV, Rutland RO: Effect of intravenous isoproterenol on theophylline kinetics. J Allergy Clin Immunol 69:360-364, 1982

63. Pang, LM, Rodriguez-Martinez F, Davis WI, Mellins RB: Terbutaline in the treatment of status asthmaticus. Chest 72:469-473, 1977

64. Santo M, Sidi $Y$, Pinkhas $Y$ : Acute myocardial infarction following intravenous salbutamol. $S$ Afr Med J 58:394, 1980

65. Downes J], Wood DW: Mechanical ventilation in the management of status asthmaticus in children, in Eckenhoff JE (ed), Science and Practice in Anesthesia. Philadelphia, J.B. Lippincott, 1965:141-149

66. Wood DW, Downes JJ, Lecks HI: The management of respiratory failure in childhood status asthmaticus: Experience with 30 episodes and evaluation of a technique. J Allergy Clin Immunol 42:261-267, 1968

67. Simons FE, Pierson WE, Bierman CW: Respiratory failure in childhood status asthmaticus. Am J Dis Child 131:1097-1101, 1977

68. Zwillich CW, Pierson DJ, Creagh CE, Sulton FD, Schatz E, Petty TL: Complications of assisted ventilation: A prospective study of 354 consecutive episodes. Am J Med 57:161-170, 1974

69. O'Rourke PP, Crone RK: Halothane in status asthmaticus. Crit Care Med 10:341-343, 1982

70. Rogers RM, Braunstein MS, Shuman JF: Role of broncho-pulmonary lavage in the treatment of respiratory failure: A review. Chest 62(Suppl 2):95S-106S, 1972

71. Zapol WM, Snider MT, Schneider RC: Extracorporeal membrane oxygenation for acute respiratory failure. Anesthesiology 46:272-285, 1977 